\title{
Genocide and Holocaust Education at Secondary Schools in Armenia
}

\author{
Siranush Chubaryan \\ University of South Carolina
}

\section{Background}

Before gaining independence Armenian educational system did not differ at all from that of other Soviet republics. The textbooks had a great bias towards Soviet totalitarian values. The history of Holocaust and Genocide Education in Armenia is directly related to the level of Soviet Union's scholarship in this field, with access to international research and practices, with politics and state anti-Semitism. From the mid-1940s until the late 1980s, Holocaust and Genocide were completely omitted from school textbooks, or any other written material which a Soviet citizen could possibly read. The reasons for forgetting the historical facts were exclusively political. The Genocide and Holocaust memory were forgotten in different manners: omitting it in silence, destroying historical facts, and direct falsification. For instance, the word Jew was a part of prohibited vocabulary and it was eventually changed to peaceful Soviet citizens. The history textbooks of Soviet period told the reader about the Slavs who fell victim to the Nazis.

The erection of the monument to commemorate victims of Armenian Genocide was a great accomplishment. Construction of the memorial began in 1966 in response to the during which one million people protested in Yerevan for 24 hours to commemorate the 50th anniversary of the Genocide. It was completed in 1968. The Jewish Holocaust could not be mentioned even on the monuments to war casualties that were erected in Jewish cemeteries.

Since gaining independence in 1992, the deepest and the most long-term education reform has been initiated and is under the supervision of the Ministry of Education of the Republic of Armenia. It has begun in 2004 and is financed by a loan from the World Bank. The main objective of the reform is to make the educational system more relevant to the new political, economic and social environment. Naturally, social science education is being transformed too. The aims, content and structure of the social science curriculum has been and is still being updated. To a certain degree methods of teaching and learning and approaches to assessment have been changed. In addition to the scope of the new curricula and textbook materials, these texts offer colorful photos and maps as well as space-appropriate passages, which are radical departures from the previously bland, overcrowded, and imageless layout of books from the Soviet era.

\section{Purpose of the research}

The aim of this research was to understand how the Armenian Genocide and the Holocaust are taught in Armenian public secondary schools. The research was conducted from November through December 2009. 


\section{Research methodology}

This research was designed as a qualitative study that used participant class observation, interviews with participants. The observation and interview research protocol was based on the following steps. Social studies teachers in Armenia were contacted by letter and invited to participate in a pilot research project that involved semi-structured interviews and classroom observations. Eighteen secondary teachers and six principals were invited to participate. Teachers and principals who volunteered to participate were reviewed for participation in the classroom observations (history classes were observed). Participants in the observations were selected for maximum diversity (especially age/experience and gender/ethnicity). All volunteers were invited for 90 minute interviews after the school day or during weekends. This survey was conducted in $6 \mathrm{sec}-$ ondary schools of Yerevan, the capital of the Republic of Armenia, as regional schools did not show interest towards participating. Eighteen secondary school history teachers ( 3 teachers from each school) and six principals participated in the project. Four of the school principals were linguists and taught Russian or Armenian to students, and the other two principals were math teachers. The interviews covered the following questions:

- How long have you been teaching History?

- What does the national curriculum require you to teach about the Armenian Genocide?

- While teaching about the Genocide do you talk about the Holocaust?

- What kind of tools do you use while teaching Armenian Genocide and Holocaust to students (e.g. textbooks, additional text materials on the subject, online materials, presentations, site visits, etc.)?

- Do you feel the national curriculum is satisfactory, inadequate, or excellent on the Armenian Genocide, and why? On the Holocaust?

- Have you been provided specific training about how to teach Armenian Genocide and Holocaust? What was it?

- What is your evaluation of the textbooks on Armenian Genocide as well as Holocaust?

- Can you please describe in detail what happens during these lessons?

- Are these lessons consistent with the other lessons in the class, or are they taught in a different way?

- In your perception, how do the students respond to these issues?

- What are your learning goals for students regarding the Armenian Genocide? Holocaust?

- Do you think Armenia should open borders with Turkey and restore diplomatic ties with the country? Are students familiar with the Border Opening Agreement?

- Are there any points in the border opening agreement which you think should be changed?

- How old are the books used while teaching the course? Do you think there are any changes in the way these issues were addressed in the textbooks of Soviet times compared to our days? 
- What is the main difference among the book content on Genocide used during the Soviet period and the post-Soviet times?

- Do the teachers conduct any case studies while teaching the course? Do they outline the link between the Human Rights and Genocide?

- Do the teachers refer to voices of survivors, which would explain a lot to students?

- Are there any students whose great grandparents were victims and/or survivors of the Genocide and who could bring to the classroom some facts which would be interesting to discuss and be familiar with?

- How the teachers usually present the topic to students? Do they highlight only the guilt of Ottoman Empire or they also discuss the involvement of other countries and nations (specifically the role and/or the guilt of Russia in the events of 1915)? What about the Holocaust?

- Do you see important similarities or differences between the Armenian Genocide and the Holocaust?

\section{Survey results}

As mentioned above eighteen secondary school history teachers (3 teachers from each school) and six principals participated in the project. Four of the school principals were linguists and taught Russian or Armenian to students, and the other two of the principals were math teachers. For that reason they could only answer general questions about the curriculum and the class structure.

The interviews with six school principals revealed the following:

Since gaining independence in 1992, the deepest and the most long-term education reform has been initiated and is under the supervision of the Ministry Of Education of the Republic of Armenia. It has begun in 2004 and is financed by a loan from the World Bank. The main objective of the reform is to make the educational system more relevant to the new political, economic and social environment. Naturally, social science education is being transformed too. The aims, content and structure of the social science curriculum has been and is still being updated. To a certain degree methods of teaching and learning and approaches to assessment have been changed. In addition to the scope of the new curricula and textbook materials, these texts offer colorful photos and maps as well as space-appropriate passages, which are radical departures from the previously bland, overcrowded, and imageless layout of books from the Soviet era.

According to school principals, significant changes have been made in the manner which Armenian history is taught in Armenia. While the subject was always included in the curriculum, it was not given much importance, being subsumed into the broader spectrum of global and Soviet history. This approach has changed, largely due to the work of a group of academicians and educators who authored texts for $7^{\text {th }}$ and $8^{\text {th }}$ grades as well as for high school usage, which ambitiously address the beginnings of Armenian history (1600BC-1990AD).

These topics are further explored in a textbook that considers "The History of the Armenian Question," which relates to the study of the national struggle for freedom, emancipation, and recognition of the Armenian Genocide. These issues of state and 
ethnic identity provide students with a rich and introspective base of knowledge that previously was inaccessible to them. Written for a $9^{\text {th }}$ grade class level, the books are used in the curriculum followed by students who chose to pursue a humanities track after completing their $8^{\text {th }}$ grade year. In addition to the textbook, brief (to keep costs down) but comprehensive teacher manuals and professional development seminars were created, offering educators guidance in both content and in methodology. Funding for these materials - which went through a second printing due to high demand came from both a private donor (World Bank) and the Armenian Educational Foundation.

The interviews with 18 history teachers revealed the following:

Three teachers from each school participated in the survey. They were all very enthusiastic to participate in the research project. To ensure the diversity teachers of different age professional experience and gender volunteered. 7 teachers had 5 to 6 years of experience and were trained after Armenia gained independence. They got their secondary and high education both in Soviet and independent Armenia. Three teachers had 9 to 11 years of teaching experience and were trained as well as educated in Soviet Armenia. 4 teachers had 12 years of experience and other 3 teachers had 25 years of teaching experience and one teacher had 30 years of teaching experience. They were all educated in Soviet Armenia. Overall 5 male teachers and 13 female teachers participated in the survey.

All 18 teachers participating in the survey mentioned that the national curriculum has changed a lot after the independence of Armenia. Now the Genocide issue is discussed more than during the Soviet times. They have mentioned that only $8^{\text {th }}$ and $9^{\text {th }}$ grade students are taught about Genocide. The Genocide course is taught only twice (4 days during late March-April period, 2 hours each day) during the spring semester to $8^{\text {th }}$ as well as $9^{\text {th }}$ grade students, which means that overall only 8 hours of the national history curriculum is devoted to Genocide class. All teachers participating in the survey teach all aspects of History (Ancient History, World History, Armenian History.) Genocide is included as a separate topic in the textbooks of Armenian History for $8^{\text {th }}$ and $9^{\text {th }}$ graders.

...I think that the time curriculum devotes to the issue of Genocide is not much. There should be more courses and Genocide should cover at least $50 \%$ of the textbooks, though there are many other aspects in our history to teach, since we are an ancient nation and we have a rich history.

... Genocide is taught only to $8^{\text {th }}$ and $9^{\text {th }}$ graders, but I think we can start from the $6^{\text {th }}$ grade, because there is much more to be discussed.

16 out of 18 teachers indicated that they just mention that during the World War II mass killing of Jewish population was organized by Nazi Government. They outlined that even in World History books there is only one sentence mentioned about the Holocaust, which means that students learn nothing about it. The reason is that even after the books were re-printed and brought to a new shape, they still keep the old Soviet content in some 
parts of historical aspects, especially when it comes to World History as well as Ancient History.

... The Holocaust is still missing from the textbooks. I mean, Holocaust as a huge historical fact as it is. It is because the Soviet content of the World History textbook has not changed much after the re-printing of the books. I don't know why it is the way it still is, but maybe Ministry of Education does not think of it as an important aspect to teach.

...The Holocaust, well, the textbook does not provide with much information and we have to stick to what is written there. We can hardly get curricular time with Genocide...

While talking about Holocaust, all 16 teachers said that they usually mention the famous phrase "Who, after all, speaks today of the annihilation of the Armenians?" The other two teachers mentioned that they never talk about Holocaust as they think that in other countries of the world students have no idea about the Armenian Genocide.

...You know it hurts, when you realize that Armenian Question is ignored in many countries. They all know about The Holocaust and no one asks "What if there was no Armenian Genocide, Would Nazis dare to kill Jews? Would the Holocaust happen?" This is a serious question, which is unfortunately ignored by many countries. This is a way to build our national identity, well we are the first to adopt Christianity, but still we have history, we have a great history. As soon as the world starts teaching about the Genocide, I will start teaching my students about the Holocaust.

...I don't teach the Holocaust. But I teach the Genocide. The Holocaust happened because long before it the Genocide occurred. You asked me why I don't teach the Holocaust. I am asking you a question back "Why Americans don't teach the Armenian Genocide? Why they promise and don't recognize it?

Reflecting on the pedagogical methodology and tools, most of the teachers participating in the survey mentioned that a lot of outside sources and tools are used while teaching the Genocide. All 17 teachers take students to the Monument of Genocide as well as to Genocide Museum where there are a lot of photographs which actually are quite informative and important. Three teachers mentioned that besides doing so they also show movies as well as documentaries to students, where the historical facts of Genocide are told. Two teachers mentioned that they require the students to make presentation on Armenian Genocide by gathering information from the internet. 
... Since I do not have many classes to teach the Genocide, we organize extracurricular activities.

I take my students to the Monument of Genocide, Tell them how in Soviet times Armenians could organize demonstration and make Soviet Government agree to build the monument and commemorate all Armenians massacred by Ottoman Empire. I also take them to the Museum of Genocide.

...Besides going to the Monument and Museum, I bring movies and we watch together after which we discuss. The students are always interested and they come ready to class, because everyone cares about the Armenian Genocide.

...I tell my students to prepare presentation. Sometimes they even use Power Point. You know it is not really used in Armenian schools, but my students do. And of course we go to Tsitsernakaberd (Monument of Genocide) and I take them to the Museum as well. There are guideshistorians who tell them more about Genocide...

Only one teacher mentioned that he just uses materials from other books in order to present the history of Genocide in a more academic manner. He was actually against taking the students to the Genocide museum as he thought that students are vulnerable to perceive and understand the historical facts.

...I used to take my students to the Monument of Genocide. We also used to go to the Museum. But one day one of my students cried right near the Monument. And we couldn't calm her down for 3 hours. She was sitting near the Monument and crying, she couldn't even move. We had to call her parents. When they arrived they explained that her grandfather was a Genocide survivor. So, they had told many stories to her which made her really upset. And she was not the only case. Once I put "Depi Ararat" (Towards Ararat) movie in the class and 70\% of students were really upset, they couldn't even talk after the movie. I really thought that I should not go beyond the academic material. I myself, feel very vulnerable when I talk about the Genocide.

All the teachers thought the national curriculum to be satisfactory on the Armenian Genocide. None of the 18 teachers mentioned that they conducted case studies while explaining the issue of Genocide. All the materials presented by teachers to students are based on text books. The teachers also stated that they just mention but that they do not explain to students that Genocide is directly related to the issue of Human Rights, since the students have a separate subject, which explains in general what Human Rights are and how the issue of Genocide is related to it. The subject is taught to $9^{\text {th }}$ and $10^{\text {th }}$ graders and it is called Legal studies. 
...the national curriculum is satisfactory, but it's not good. Out of 5 points it is 3. I would add more material to what there is in the text books. Also, I would add hours for teaching Genocide and I would go down at least to $7^{\text {th }}$ grade as well.

...Well, the national curriculum, it's, well satisfactory after the Soviet one. But could be better. And as to Human Rights, remember the Convention on the Prevention and Punishment of the Crime of Genocide? I always mention the relation between the Human Rights and any Genocide or crime against the humanity. But they have separate Human Rights/Social Studies class. I think they should have it there.

As to Holocaust, 16 teachers found the textbook materials for teaching the Holocaust completely inadequate for non-Soviet textbooks. As mentioned above only two mentioned it not to be important for Armenian students.

....Material on the Holocaust? I will just say two words. Only two sentences in the World History Book and no curricular time for that. How can I teach it?

...There is no material on the Holocaust, whatever there is, is completely inadequate for a textbook printed after the Soviet Union.

...I think there are two words mentioned in the World War 2 section. It does not make any sense, as if it never happened.

None of the teachers was provided any type of training on how to teach Genocide or Holocaust.

...I have never had any kind of training. It is bad, I know. It will be good to know how to teach Genocide or Holocaust.

...I was always wondering if there could be a group of international experts who could train us. I know that the Holocaust is widely taught abroad. So, maybe there are experts who could train us.

...I even wrote to the Ministry of Education as well as to The National Institute of Education and requested to train us in how to teach the Genocide. But no reply.

Teachers evaluated the text books satisfactory especially as compared to those of Soviet period. During the Soviet times the topic was not discussed in detail, the content of the subject did not present important facts, the word Genocide was prohibited. As to 
Holocaust, nothing has changed since Soviet times. The content did not include any details and it is presented the same way till now. The new textbooks for all history aspects taught at secondary schools were published in 1999 after the independence of Armenia. In 2007 the books were re-published but since 1999 the content has not changed. Teachers evaluated the content of the textbook satisfactory but not good enough to provide with all the necessary information they think they should. All of the teachers mentioned that the books are not "user-friendly" as they are written in a very academic and lecture like manner which is actually not acceptable for 13-14 years old children. They mentioned that the material should be presented in a more interesting way so that students face no difficulty remembering the historical facts as well as data. Regarding the Holocaust teachers evaluated the books as inadequate.

...I don't even want to compare to what we had back in Soviet times. But still it is just satisfactory. And also the way it is written. You need an interpreter as well to translate from academic Armenian to standard one, which kids can understand.

...Well, the textbooks, are satisfactory, but there is many more which should be added. Oh, I forgot to say the language they use in the textbooks is terrible. I go home and read, after which I explain to my students, so that they don't get lost while reading .

...The Holocaust material is completely inadequate. I can say that there is nothing mentioned about the Holocaust. Well, at least they could have included a page of discussion. It is the same as back in Soviet times. Though, the Genocide part was added after re-printing, but is still not good enough.

The classes conducted by all teachers came to have the following structure: usually the Genocide classes are taught during the spring semester right before the commemoration of Armenian Genocide day, the $24^{\text {th }}$ of April. The very first class normally looks like a lecture where the facts and data are presented to students based on the book. During the second day of the class, students usually present the material and they may bring different materials from internet, they may tell outside facts and stories which were not presented in the textbook. The second day of the class usually has a discussion format. Since the curriculum requires teaching only 4 hours of Genocide course per year, the teachers organize an extracurricular one-day activity which includes: visiting the Genocide Museum together with the monument, movie watching. To structure the class it would look like the following: Lecture-Discussion/outside sources presented by students-Site visit/movies.

The teachers mentioned that all classes at school are taught the same way. The only difference is that to present the Genocide topic they use extracurricular activities.

The teachers indicated that the students respond differently to the issue related to 
Genocide. 30\% of students still view Turkish people as the worst enemies of Armenian nation. According to teachers the prejudice students have towards Turkish mostly comes from their families. But there are many students that fortunately think that ordinary Turkish people actually have no guilt related to the Genocide of 1915 .

...There was a student in my class that told that he is going to kill a Turk. He said he would hate them forever and teach his kids to hate them as well...The way his parents taught him.

...A student told me that his grandmother always talked about Turkish people as our enemies and as people who would always kill Armenians. My student explained her hatred towards Turks that way.

Still students get very emotional when they are taught about Genocide.Two of the teachers mentioned that there were cases when students were crying during the Genocide class.

...One of my female students was crying out loud, she was really upset, so we have to stop the discussion and talk to her for a while. Then she just left and said that she could not continue sitting in the class.

... Once we were watching a movie and most of the class would cry. It was a documentary, you know, one of the films about Genocide. Almost everyone was crying...me too.

There were even cases when great grandparents of the students were survivors of Genocide and they could bring interesting materials to present it during the class. Those materials were very interesting and all the students were actually very excited to discuss them in the class.

The main goals while teachers teach the Genocide and rarely indicate Holocaust $95 \%$ of teachers answered that they try to change the existing prejudice, to explain that besides the Ottoman Empire there were also other powerful countries like Great Britain, Germany and Russia who played a great role in the events of 1915. Teachers avoid highlighting the guilt of Russia, since Armenia is totally dependent from Russian Federation even now.

...Russia, Russia has always been our supporter and still is. Can you imagine what faith Armenian would have without Russians. I personally cannot imagine Armenia without Russia.

...I just mention the role of mega-powers of that period, like Germany. I do not really feel like discussing Russia's role, because first of all it's not in the textbook and secondly...I just don't want. 
...Of course Russia is mentioned, everything should be mentioned. That's what the history shows. And I am trying to explain to my students that we cannot live on with hatred towards Turkey and Turkish. We should try to build a dialogue. Of course I mention Russia, since it has changed Armenia's faith all along these years...

...Though Russia is not discussed very much in our textbooks, I do mention it and also I tell my students that whatever is going negative with Armenia now, it's all because of Russia. It has always been like that. Also, I do not blame the present Turkish generation. I tell my students not to hate them and be tolerant.

Only one of the teachers added that she tries to explain crimes against humanity while explaining the issues of Genocide and Holocaust.

...I always mention that Genocide and the Holocaust following it are the worst crimes against humanity. I bring examples from violations of Human Rights, and try to put Genocide and the Holocaust in one line with Human Rights...

All eighteen teachers were for opening the borders with Turkey and restore the diplomatic ties with the neighboring country, since it is quite important for the future development of Armenia. The teachers mentioned that the borders should be opened without any pre-conditions presented by Turkey. Most of the teachers indicated that some points of the Protocol should definitely be changed (e.g. Formation of commission involving Turkish and Armenian scholars to research if Genocide really happened or not). I also got a chance to talk to 20 students. Only students of 2 schools (overall 5 students) out of six were familiar with the Protocol and most of them think that the borders should be opened.

...Well, times have passed and we cannot live in blockade all the time. We cannot always hate Turkish people. If we open the borders they might recognize Genocide, or maybe not...

...We go to Turkey every summer to have vacation there. What is the difference, with closed or opened borders. It is better to open...

The main differences between the Genocide and the Holocaust that the teachers mentioned were the following:

- There were no hate speeches in the Ottoman Empire against Armenians; there were in Nazi Germany.

- Jews were hated and prejudiced against before the Nazi regime; Hitler acted on these age- old prejudice, however there didn't exist such biased attitude between Armenians and Turks. 
- Armenians were killed in their homeland while Jews lived all over the world far from their homeland.

- Jews were isolated into communities known as Ghettos. Armenians were not secluded but some villages were known to be populated mostly by Armenians.

\section{Conclusion}

This brief research shows that despite the fact that the Republic of Armenia is an independent country now, there are many historical events (e.g. the Holocaust) still kept in silence. The research makes obvious that the Armenian general educational system needs improvements. Those improvements should primarily start from changing the text-book content and making easily perceivable for students; training the teachers as they do need training and they do need to be updated with new materials; making extra-curricular activities at least part of Armenian History curriculum; re-print the World History books and make the Holocaust material at least more profound, so that students could relate the Genocide and the Holocaust. The literature review revealed that none of the activities conducted in different countries of the world exist in Armenian curriculum. All the problems create a huge gap in both teaching and learning process, and if Armenians want to make the Genocide part of their national identity, the school curriculum should definitely be revised.

The author would like to express her gratitude to Holocaust Council of South Caroline for their support in publishing the article which summarizes some of the results of the long-term project she has undertaken.

\section{Notes:}

1. According to the American journalist Louis P. Lochner, while stationed in Berlin he received a copy of a speech by Hitler from his "informant", which he published (in English translation) in his book What About Germany? (New York: Dodd, Mead \& Co., 1942) as being indicative of Hitler's desire to conquer the world. In 1945, Lochner handed over a transcript of the German document he had received to the prosecution at the Nuremberg trials, where it was labeled $L-3$. Hence it is known as the $L-3$ document. "The Times" of London quoted from Lochner's version in an unsigned article titled The War Route of the Nazi Germany on November 24, 1945. The article stated that it had been brought forward by the prosecutor on November 23, 1945, (i.e. the previous day), as evidence. However, according to the Akten zur deutschen auswärtigen Politik (ser. D, vol. 7, 1961), the document was not introduced as evidence before the International Military Tribunal and is not included in the official publication of the documents in evidence. Two other documents containing minutes of Hitler's Obersalzberg speech(es) had been found among the seized German documents and were introduced as evidence; neither, however, contains the Armenian quote.

2. http://www.hrweb.org/legal/genocide.html 


\section{References:}

1. Abowitz, D.A. (2002) Bringing the Sociological into the Discussion: Teaching the Sociology of Genocide and the Holocaust. // Teaching Sociology, 30(1), 26-38. / Ed. by K.S. Lowney. Valdosta: Valdosta State University Press.

2. Adalian, R. (1987) How and Why to Teach the Armenian Genocide: Seeking a Humanist Perspective. // Armenian Review, 40(1), 69-77. / Ed. by R.G. Hovhannisian. Watertown: MA.

3. Baker, R.W. (1989) Facing History and Ourselves: Curriculum produces political debate. // Curriculum Review, 28(6), 4-10. NY: Paperclip Communications.

4. Brenner, R.F. (1999) Teaching the Holocaust in Academia: Educational Mission(s) and Pedagogical Approaches. // Journal of Holocaust Education, 8(2), 1-26. Oxford: Taylor and Francis Group.

5. Fleming, D. (1987) Genocide in World History Textbooks. // Social Science Record, 24(2), 48-51. Boston: Harvard University Press.

6. Johnson, M. (1989) Meeting the Challenges of Teaching the Armenian Genocide in American Secondary Schools: Approaches and Resources. // Paper presented at a Conference entitled "The Armenian Genocide: History, Politics, Ethics". Columbia: University of South Carolina Library Source.

7. Pugach, N.H. (1987-1988) Teaching the Armenian Genocide to College Students: A report. // National Association for Armenian Studies and Research Newsletter, 4(4), 4, 6. Boston: Harvard University Press.

8. Wrenn, A. (2001) "Who, after all, Speaks Today of the Annihilation of the Armenians?"// Teaching History, 104 (September), 54-59. London, UK: The Historical Association.

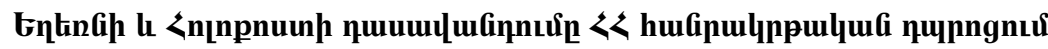

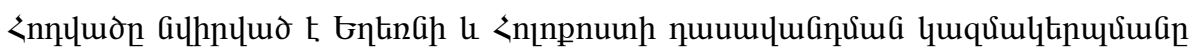

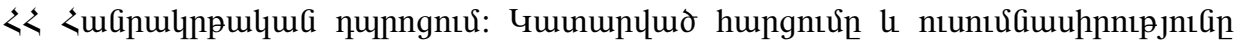

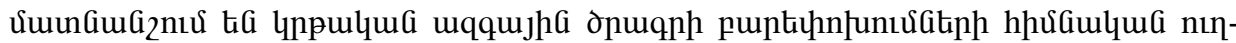

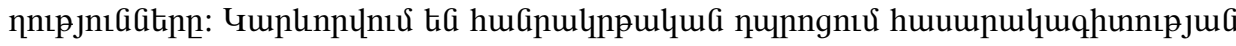

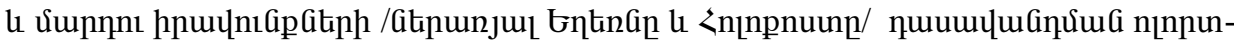

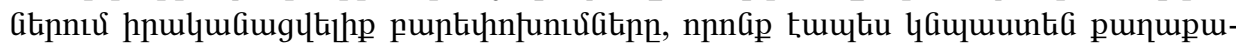

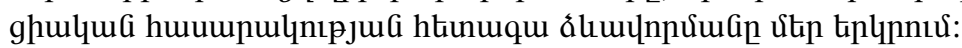

